\title{
Efek Antioksidan pada Teh Hijau terhadap Kadar Kolesterol Darah
}

\author{
Brigita T. Tamon, ${ }^{1}$ Murniati Tiho, ${ }^{2}$ Stefana H.M. Kaligis ${ }^{2}$
}

\author{
${ }^{1}$ Program Studi Pendidikan Dokter Fakultas Kedokteran Universitas Sam Ratulangi \\ Manado, Indonesia. \\ ${ }^{2}$ Bagian Biokimia Fakultas Kedokteran Universitas Sam Ratulangi Manado, Indonesia \\ Email: brigitatirza@gmail.com
}

\begin{abstract}
Hypercholesterolemia, a condition when blood cholesterol levels exceed the normal value can lead to atherosclerosis and furthermore coronary heart disease. For that reason, some treatment actions are needed, one of which is by given hypolipidemic drugs. One of the natural remedies that act as hypolipidemic drugs is green tea. Green tea contains catechins, one of the antioxidant compounds. Catechins, especially epigallocatechin-3-gallate (EGCG), plays an important role in lowering blood cholesterol levels. The aims of this study is to determine the effect of antioxidants in green tea on blood cholesterol levels. This is a literature review study with data retrieved using 3 databases: Pubmed, ClinicalKey and Google Scholar. Using Green Tea OR Teh Hijau, Cholesterol OR Kolesterol, and Antioxidant OR Antioksidan as keywords and limiting the article searching based on inclusion and exclusion criteria, 12 studies was found to be reviewed. From 12 literature reviewed using experimental research methods with human and animal subjects with intervention green tea (extract, EGCG and PPE), all of them showed a significant reduction in blood cholesterol levels after the intervention with green tea. In conclusion, the antioxidants in green tea can reduce cholesterol levels in the blood.
\end{abstract}

Keywords: antioxidant, green tea, EGCG, cholesterol, hypercholesterolemia

\begin{abstract}
Abstrak: Kadar kolesterol yang melebihi batas normal atau biasa disebut hiperkolesterolemia dapat menyebabkan pembentukan aterosklerosis bahkan penyakit jantung koroner. Untuk itu diperlukan penanganan, salah satunya dengan pemberian obat hipolipidemia. Salah satu bahan alami yang dapat berperan sebagai hipolipidemia yaitu teh hijau. Teh hijau mengandung senyawa antiosidan yaitu katekin terutama epigallocatechin-3-gallate (EGCG) yang berperan penting dalam menurunkan kadar kolesterol dalam darah. Tujuan penelitian ini untuk mengetahui efek antioksidan pada teh hijau terhadap kadar kolesterol dalam darah. Penelitian ini berbentuk literature review dengan pencarian data menggunakan 3 database yaitu PubMed, ClinicalKey dan Google Scholar. Kata kunci yang digunakan yaitu Green Tea OR Teh Hijau, Cholesterol OR Kolesterol, dan Antioxidant OR Antioksidan. Setelah diseleksi berdasarkan kriteria inklusi dan eksklusi, didapatkan 12 literature yang di review. Dari 12 literature yang di review menggunakan metode penelitian eksperimental dengan subjek penelitian manusia dan hewan yang diberi teh hijau (ekstrak, EGCG dan PPE) semuanya menunjukkan hasil adanya penurunan kadar kolesterol darah yang signifikan setelah diberikan teh hijau. Sebagai simpulan, antioksidan pada teh hijau dapat menurunkan kadar kolesterol dalam darah.
\end{abstract}

Kata Kunci: antioksidan, teh hijau, EGCG, kolesterol, hiperkolesterolemia

\section{PENDAHULUAN}

Kolesterol yang berlebihan di dalam tubuh dapat menyebabkan berbagai penyakit terutama penyakit jantung coroner. ${ }^{1}$ Menurut data Global Health dari World Health Organization (WHO) tahun 2016 menunjukkan bahwa prevalensi kolesterol tinggi di kalangan orang dewasa ( $\geq 90 \mathrm{mg} / \mathrm{dl}$ ) adalah rata-rata $39 \%$ (37\% pada pria dan $40 \%$ untuk wanita). 
Kolesterol tinggi meningkatkan risiko terkena penyakit kardiovaskular, stroke dan bertanggung jawab atas 2,6 juta kematian serta menyebabkan 29,7 juta lainnya akan mengalami Disability Adjusted Life Year (DALYs) setiap tahun. $^{2}$ Di Indonesia, data yang diambil dari hasil Riset Kesehatan Dasar Nasional (RISKESDAS) tahun 2018 menunjukkan ada $21,2 \%$ dari penduduk Indonesia yang berusia $\geq 15$ tahun dengan kadar kolesterol tinggi dengan kadar kolesterol $\geq 200 \mathrm{mg} / \mathrm{dl}$ (berdasarkan National Cholesterol Education Program, Adult Treatment Panel III), dimana wanita (24\%) lebih banyak dari pria $(18,3 \%){ }^{3}$

Oleh karena ada banyak penyakit yang ditimbulkan akibat hiperkolesterolemia, maka dari itu diperlukan penanganannya, salah satunya menggunakan obat hipolipidemia. Penggunaan bahan alami sebagai obat tradisional di Indonesia sudah dilakukan sejak berabadabad yang lalu. Salah satu faktor yang menyebabkan banyak orang lebih memilih menggunakan obat tradisional karena penggunaan obat modern memiliki efek samping yang relatif lebih besar daripada obat tradisional. ${ }^{4,5}$ Salah satu bahan obat tradisional yang berpotensi sebagai hipolipidemia yaitu teh hijau.

Teh hijau merupakan teh alami karena tidak mengalami proses fermentasi sehingga zat-zat yang terdapat di dalam teh hijau belum mengalami proses perubahan. Selain itu, teh juga sangat mudah ditemukan dan umum digunakan sebagai minuman sehari-hari. Kandungan teh hijau yang paling utama adalah epigallocatechin-3-gallate (EGCG) yang merupakan bahan bioaktif yang menekan patogenis beberapa penyakit kronis khususnya penyakit kardiovaskular. Teh hijau juga memiliki efek farmakologis antara lain dapat menurunkan berat badan, menurunkan kolesterol, trigliserida, serta glukosa darah. ${ }^{6-9}$

Besarnya manfaat dari teh hijau terhadap penurunan kadar kolesterol bisa dilihat pada beberapa penelitian yang sudah dilakukan. Adanya pemberian teh hijau dapat menurunkan kadar kolesterol pada lansia awal (46-55) tahun. ${ }^{10}$ Pemberian suplemen obat yang berisi ekstrak teh hijau juga dapat menurunkan kadar kolesterol total dan konsentrasi dari Low Density Lipoprotein (LDL) pada wanita postmenopausal. ${ }^{11}$ Selain itu, didapatkan adanya penurunan kadar kolesterol dan peningkatan leptin pada wanita yang kelebihan berat badan dan obesitas ketika diberikan teh hijau. ${ }^{12}$ Penelitian yang dilakukan terhadap hewan dalam hal ini tikus wistar diabetes yang diinduksi aloksan menunjukkan bahwa ekstrak teh hijau dapat menurunkan kadar kolesterol. ${ }^{13}$ Tujuan penelitian ini untuk mengetahui efek antioksidan pada teh hijau terhadap kadar kolesterol dalam darah.

\section{METODE PENELITIAN}

Penelitian ini merupakan penelitian deskriptif yang berbentuk literature review yang dilakukan dengan cara identifikasi, evaluasi dan interpretasi terhadap semua hasil penelitian tertentu, topik tertentu atau fenomena yang menjadi perhatian. Literature review merupakan rangkuman menyeluruh beberapa studi penelitian yang ditentukan berdasarkan topik tertentu. Data yang digunakan yaitu data sekunder yang diperoleh bukan dari pengamatan langsung, akan tetapi diperoleh dari hasil penelitian yang dilakukan oleh penelitipeneliti terdahulu. Dilakukan pencarian data berupa jurnal penelitian dengan menggunakan tiga database yaitu PubMed, ClinicalKey dan Google Scholar. Kata kunci yang digunakan dalam pencarian yaitu Green Tea OR Teh Hijau, Cholesterol OR Kolesterol, dan Antioxidant OR Antioksidan.

\section{HASIL PENELITIAN}

Berdasarkan pencarian literatur melalui 3 database elektronik, peneliti mendapatkan artikel sebanyak 875 menggunakan Pubmed, 716 menggunakan Clinical Key dan 3.160 menggunakan Google Scholar $(\mathrm{n}=4.751)$. Setelah 
dilakukan pencarian, disesuaikan dengan kriteria inklusi dan eksklusi, kemudian dieksklusi. Hasil seleksi akhir didapatkan
12 literatur yang memenuhi kriteria dan lolos tahap seleksi (Tabel 1).

Tabel 1. Keterangan Studi yang dimuat pada literatur

\begin{tabular}{|c|c|c|}
\hline $\begin{array}{l}\text { Penulis, } \\
\text { tahun }\end{array}$ & Study Design & Population \\
\hline $\begin{array}{l}\text { Mawarti } \\
\text { dan } \\
\text { Ratnawati, } \\
2012^{14}\end{array}$ & $\begin{array}{l}\text { Eksperimental } \\
\text { laboratorik } \\
\text { dengan } \\
\text { Rancangan } \\
\text { Acak Lengkap }\end{array}$ & $\begin{array}{l}25 \text { ekor tikus } \\
\text { wistar }\end{array}$ \\
\hline $\begin{array}{l}\text { Wu, } \\
2012^{15}\end{array}$ & $\begin{array}{l}\text { Double-blind, } \\
\text { randomized, } \\
\text { placebo- } \\
\text { controlled } \\
\text { intervention }\end{array}$ & $\begin{array}{l}103 \text { wanita } \\
\text { post- } \\
\text { menopause }\end{array}$ \\
\hline
\end{tabular}

Suliburska, A randomized, 46 pasien $2012^{16} \quad$ double-blind, obesitas placebocontrolled

$\begin{array}{lll}\text { Ekanto, } & \begin{array}{l}\text { Eksperimen } \\ \text { (post test } \\ \text { control group }\end{array} & 9 \text { ekor mencit } \\ & \text { jesaintan }\end{array}$

Chen, A randomized, 92 wanita $2015^{18} \quad$ double-blind, dengan placebo- obesitas controlled sentral clinical trial

Samavat, A randomized, $2016^{11} \quad$ placebocontrolled clinical trial

Harahap, Eksperimental $2016^{19} \quad$ (Post test only control group design)

1075 wanita postmenopause (yang penelitian hanya 936)

\section{Intervention/comparator}

Outcomes

Dibagi dalam 5 kelompok: (1) Hasil penelitian menunjukkan diet pakan standar; (2) diet EGCG menurunkan TC $(p<$ tinggi lemak; (3) diet tinggi 0.05). Kadar TC menurun lemak + EGCG $1 \mathrm{mg} / \mathrm{kgBB}$; (4) signifikan sebesar $55 \%(p=$ diet tinggi lemak + EGCG 2 0.00) pada dosis $8 \mathrm{mg} / \mathrm{kgBB}$ $\mathrm{mg} / \mathrm{kgBB}$; (5) diet tinggi lemak jika dibandingkan dengan + EGCG 8 mg/kgBB. Perlakuan kelompok kontrol positif. selama 60 hari.

Populasi dibagi 3 kemudian LDL-C menurun signifikan diberikan plasebo, 400mg PPE pada kelompok PPE; atau $800 \mathrm{mg}$ PPE sediaan perubahan LDL-C berbeda kapsul, setiap hari dalam 2 antara kelompok plasebo dan bulan. PPE $(p=0.02)$. Tidak ada perubahan yang signifikan pada TC, HDL-C dan TG.

379 mg GTE atau plasebo Penurunan TC, LDL-C dan diberikan secara acak, setiap TG. Dikonfirmasi efek yang hari dalam 3 bulan. menguntungkan GTE terhadap IMT, profil lipid dan status antioksidan total pada pasien obesitas.

Dibagi 3 kelompok, A (tidak Rerata kadar TC kelompok A diberi diit tinggi lemak), B 116,33 mg/dl, kelompok B 201 (diberi diit tinggi lemak) dan C mg/dl dan kelompok C 142 (diberi diit tinggi lemak dan teh $\mathrm{mg} / \mathrm{dl}$. Teh hijau mencegah hijau). Diberi $0.52 \mathrm{cc}$ teh hijau, kenaikan kadar kolesterol pada menggunakan pipa makanan kelompok $\mathrm{C}(p=0.003)$ (disonde), selama 28 hari.

Dibagi 2 kelompok, teh hijau Terdapat penurunan berat dosis tinggi (EGCG) dan badan yang signifikan $(p=$ plasebo. Total waktu perawatan 0.025), serta penurunan IMT 12 minggu. $\quad(p=0.018)$ dan lingkar pinggang $(p=0.023$ pada kelompok dengan dosis tinggi EGCG. Terdapat penurunan TC yang konsisten hingga $5.33 \%$ dan penurunan kadar LDL.-C Dibagi 2 kelompok yang Penurunan signifikan pada TC
menerima GTE dan plasebo. $(22.1 \%, p=0.0004)$, LDL-C Diberikan 4 GTE (satu kapsul $(24.1 \%, p=0.0001)$ dan nonmengandung $843 \mathrm{mg}$ EGCG) HDL-C $(23.1 \%, p=0.0032)$. menyelesaikan setiap hari selama 12 bulan. Peningkatan TG (3.6\%) pada kelompok GTE dan penurunan $(2.5 \%)$ pada kelompok plasebo $(p=0.046)$.

15 ekor mencit Dibagi kelompok I (kontrol Adanya perubahan rerata pada jantan negatif), kelompok II (30 TC dan HDL-C pada $\mathrm{mg} / \mathrm{kgBB}$ teh hijau) dan kelompok yang diberikan teh kelompok III $(37,5 \mathrm{mg} / \mathrm{kgBB}$ hijau $(p=0.008)$. Tidak teh hijau). Penelitian dilakukan terdapat perbedaan yang selama 30 hari. 
0.279) dan HDL $(p=0.691)$ pada kelompok II dan III.

Astari dkk, Pra eskperimen 10 lansia awal Diberikan 3 gr teh hijau yang Rerata kadar TC sebelum $2017^{10}$ dengan one (46-55 tahun) dicampur $200 \mathrm{ml}$ air hangat, pemberian teh hijau 241,4 group pre testdiberikan $2 \mathrm{x}$ sehari selama $7 \mathrm{mg} / \mathrm{dl}$ dan rerata kadar TC hari. setelah pemberian teh hijau $214,1 \mathrm{mg} / \mathrm{dl}(p=0.002)$.

Huang, A randomised, 90 wanita $2018^{12} \quad$ double-blind, overweight and cross-over dan obesitas placebocontrolled clinical trial

$\begin{array}{lll}\text { Erlyn, } & \begin{array}{l}\text { Pretest- } \\ \text { posttest } \\ \text { control group }\end{array} & \text { 25 ekor tikus } \\ & \text { jantan galur } \\ & \text { Wistar } \\ & \text { design }\end{array}$

Dibagi dua, grup A menerima Penurunan signifikan LDL-C GTE selama 6 minggu dan grup sebesar 4.8\% $(p=0.048)$ dan B plasebo. Setelah 6 minggu peningkatan leptin sebesar pengobatan dan 14 hari 25.7\% ( = 0.046). Tidak ada washout period, perlakukan perbedaan statistik kadar TC, grup A dan B ditukar. Satu TG, dan HDL-C antara kapsul GTE (856.8 mg EGCG), kelompok GTE dan plasebo. $3 x$ sehari, selama 6 minggu.

Tikus disuntik pakan lemak Hasil analisis kelompok tinggi selama 14 hari. dengan ekstrak teh hijau dan Kemudian tikus dibagi menjadi daun pare menurunkan kadar 5 kelompok (kontrol negatif; TC secara signifikan. Ekstrak ekstrak daun pare $60 \mathrm{mg} / \mathrm{kgBB}$; teh hijau $100 \mathrm{mg} / \mathrm{kgBB}$ ekstrak daun pare 120 menurunkan kolesterol lebih $\mathrm{mg} / \mathrm{kgBB}$; ekstrak teh hijau 50 tinggi dari kelompok lainnya. $\mathrm{mg} / \mathrm{kgBB}$; ekstrak teh hijau 100 $\mathrm{mg} / \mathrm{kgBB}$. Dinilai pada hari ke 30.

Maydawati Quasi eksperi- 34 orang , 2020 $21 \quad$ men dengan akseptor KB pendekatan DMPA pretest posttest dengan control group hiperkolestedesign rolemia Sarel, True $2020^{13}$ experimental jantan galur Wistar

Dibagi kelompok kontrol dan Terdapat penurunan kadar TC intervensi. Pada kelompok dari 231,3 $\pm 6,5 \mathrm{mg} / \mathrm{dl}$ menjadi intervensi diberikan teh hijau $179 \pm 6 \mathrm{mg} / \mathrm{dl}(p<0.05)$. 2,4 gr per hari selama 14 hari.

Dibagi 6 kelompok (K1 Hasil menunjukkan GTE perlakuan normal, K2 diinduksi efektif dalam mengurangi TC aloksan, K3 diinsuksi aloksan $(p=0.000)$. GTE dengan dosis dan simvastatin, K4 aloksan $400 \mathrm{mg} / \mathrm{kgBB}$ sebanding dan GTE $200 \mathrm{mg} / \mathrm{kgBB}$, K5 dengan simvastatin dalam aloksan dan GTE 400 menurunkan kadar TC $\mathrm{mg} / \mathrm{kgBB}, \mathrm{K} 6$ aloksan dan GTE mendekati normal $(p=0.453)$ $800 \mathrm{mg} / \mathrm{kgBB})$ dan perlakuan selama 16 hari.

*p = nilai probabilitas $;$ GTE $=$ Green Tea Extract $;$ PPE = Polyphenon E $;$ EGCG =Epigallocatechin-3-Gallate; IMT = Indeks Massa Tubuh; $\mathrm{TC}=$ Total Cholesterol $;$ LDL-C = Low Density Lipoprotein-Cholesterol; HDL-C = High Density Lipoprotein-Cholesterol TG = Trigliserid .

\section{BAHASAN}

Hasil penelitian secara umum menunjukkan adanya penurunan kadar kolesterol pada objek penelitian yang diberikan teh hijau. Hal ini dikarenakan teh hijau mengandung polifenol utama yaitu katekin yang terdiri dari epicatechin, epigallocatechin, epicatechin-3-gallate dan epigallocatechin-3-gallate. Komponen utama pada katekin ialah EGCG $(59 \%)$ yang merupakan antioksidan dengan kekuatan 4-5 kali lebih tinggi dibandingkan vitamin $\mathrm{E}$ dan vitamin $\mathrm{C}^{14}$
Penelitian yang dilakukan dengan objek penelitian hewan yaitu pada tikus Wistar dan mencit ${ }^{13,14,17,19,20}$ menunjukkan pemberian ekstrak teh hijau menyebabkan terjadi penurunan kadar kolesterol total darah. Penelitian dari Erlyn (2020) menemukan perbandingan teh hijau dengan pemberian sumber antioksidan lain yang dapat menurunkan kadar kolesterol darah lebih tinggi dibandingkan ekstrak daun pare. ${ }^{20}$ Selain itu, penelitian lain yang dilakukan oleh Astuti (2020) yang menggunakan yoghut dan soyghurt 
sinbiotik kayu manis untuk melihat efeknya terhadap total kolesterol darah pada tikus pra-sindrom metabolik, menunjukkan hasil yang tidak signifikan. ${ }^{22}$ Penurunan kadar kolesterol total pada pemberian ekstrak teh hijau dikarenakan adanya kandungan senyawa metabolit sekunder pada teh hijau yaitu katekin yang dapat memperbaiki profil lipid darah dan memiliki efek vasoprotektif. $^{20}$

Berdasarkan literature yang di review, penelitian yang dilakukan pada manusia dilakukan pada empat kelompok yang dapat menyebabkan terjadinya kondisi hiperkolesterolemia. Pertama, pada kelompok kelebihan berat badan dan obesitas, ${ }^{12,16,23}$ kedua pada usia lansia, ${ }^{24}$ ketiga pada pengguna DMPA jangka panjang $^{25}$ dan keempat pada wanita postmenopause..$^{11,15}$

Dari tiga literatur yang meneliti efek antioksidan teh hijau terhadap kadar kolesterol pada kelompok kelebihan berat badan dan obesitas, dua studi, Suliburska $^{16}$ dan Chen $^{18}$ menunjukkan adanya penurunan kadar total kolesterol darah dengan pemberian teh hijau. Satu studi dari Huang ${ }^{12}$ menunjukkan tidak ada perbedaan yang signifikan antara kelompok yang diberi GTE dengan kelompok kontrol, tetapi terdapat perbedaan yang signifikan pada kadar leptin dan LDL-C. Meskipun demikian, ketiga studi menunjukkan penurunan berat badan dan IMT yang signifikan pada kelompok yang diberikan teh hijau. Peran polifenol pada teh hijau memiliki efek anti-obesitas pada homeostasis lemak dengan meningkatkan thermogenesis, mengurangi penyerapan lemak dan mengendalikan nafsu makan. ${ }^{16}$ Meskipun demikian, peran polifenol pada teh hijau memiliki efek anti-obesitas masih kurang baik dibandingkan dengan isoflavon. Penelitian yang dilakukan oleh Carolyn (2019) yang meneliti potensi pemberian isoflavon kedelai terhadap kadar kolesterol pada pasien obesitas dengan hasil menunjukkan adanya penurunan kadar kolesterol total. Bukan hanya itu, didapatkan juga penurunan kadar trigliserida, VLDL dan LDL serta dapat meningkatkan HDL. Hal ini disebabkan oleh kandungan yang terdapat pada kedelai yaitu isoflavon berpengaruh terhadap peningkatan katabolisme sel lemak untuk pembentukan energi yang berakibat pada penurunan kadar kolesterol. ${ }^{26}$ Hal ini yang menunjukkan bahwa antioksidan pada kedelai lebih besar pengaruhnya terhadap kolesterol dibandingkan dengan teh hijau.

Pada kelompok pengguna DMPA jangka panjang, kandungan flavonoid pada teh hijau telah terbukti dapat memperbaiki profil lipid darah dan memiliki kemampuan untuk menghambat CETP (Cholesteryl Ester Transfer Protein) sehingga dapat menurunkan kadar kosterol dalam darah. ${ }^{21}$ Hasil penelitian yang dilakukan oleh Hassan (2019) menunjukkan bahwa alat kontrasepsi termasuk DMPA dapat meningkatkan profil lipid namun hal ini dapat diatasi dengan penggunaan vitamin $\mathrm{E}$ yang merupakan antioksidan yang dapat menghentikan pembentukan radikal bebas. Walaupun dalam penelitian tersebut dengan pemberian vitamin $\mathrm{E}$ tidak menunjukkan adanya perubahan yang signifikan pada kadar LDL. $^{27}$ Apabila dibandingkan antara vitamin $\mathrm{E}$ dengan teh hijau dalam penelitian ini, maka yang lebih berpengaruh terhadap kadar kolesterol ialah teh hijau, karena selain dapat menurunkan $\mathrm{TC}$, teh hijau juga dapat meningkatkan kadar HDL dan menurunkan kadar LDL. Hal ini disebabkan oleh peran utama dari katekin dalam teh hijau ialah membantu kinerja enzim SOD yang berfungsi untuk menyingkirkan radikal bebas dalam tubuh dan juga sebagai penghambat CETP.

Pada kelompok usia lansia awal, polifenol yang terkandung pada teh hijau terutama katekin dapat membantu kerja enzim superoxide dismulate (SOD) yang dapat menyingkirkan radikal bebas sehingga menurunkan kadar kolesterol yang merupakan risiko tinggi terkena penyakit degeneratif. ${ }^{10}$ Dibandingkan dengan pemberian antioksidan lain 
misalnya vitamin $\mathrm{C}$ dengan subjek yang sama, katekin pada teh hijau menunjukkan hasil yang lebih baik. Penelitian yang dilakukan oleh Hapsari (2014), meneliti tentang pengaruh vitamin $\mathrm{C}$ terhadap kadar LDL lanjut usia seteleh pemberian jus lidah buaya, hasil yang didapatkan ialah pemberian jus lidah buaya menurunkan kadar LDL secara bermakna. Namun pemberian vitamin $\mathrm{C}$ tidak terbukti mempertahankan penurunan kadar LDL. Hal ini dikarenakan jus lidah buaya mengandung vitamin B3 (niasin) yang bekerja menghambat enzim hormone sensitive lipase di jaringan adiposa sedangkan fungsi vitamin $\mathrm{C}$ dalam penelitian tersebut ialah sebagai antioksidan yang turut membantu penurunan kadar LDL. Penurunan yang tidak signifikan setelah pemberian vitamin C dikarenakan subjek dalam penelitian tersebut adalah lansia sehingga membutuhkan waktu pemberian vitamin C yang lebih lama karena waktu pemberiannya hanya tiga hari. ${ }^{28}$ Jika dibandingkan pada penelitian Astari (2017) yang meneliti pengaruh teh hijau pada subjek yang sama yaitu lansia, maka dapat dilihat bahwa kadar kolesterol dapat menurun dengan waktu pemberian tujuh hari. $^{10}$

Pada kelompok wanita postmenopause, dalam penelitian ini dari dua studi yang meneliti efek antioksidan pada teh hijau, satu studi yaitu Samavat 11 menunjukkan adanya penurunan kadar total kolesterol darah. Satu studi dari $\mathrm{Wu}$ 15 tidak menunjukkan adanya perbedaan yang signifikan terhadap kadar kolesterol total, HDL-C dan TG. Meskipun demikian, kedua studi tersebut menunjukkan adanya perubahan yang signifikan terhadap LDL-C pada kelompok yang diberikan teh hijau. Peran EGCG pada teh hijau dapat menghambat hidroksil-3metil-glutaril-KoA (HMG-CoA) reduktase yang merupakan enzim yang berperan dalam pembentukan kolesterol sehingga dapat menurunkan kadar kolesterol. ${ }^{15}$ Dengan objek penelitian yang sama, hasil penelitian yang dilakukan oleh Darmawan (2018) menunjukkan adanya pengaruh yang signifikan terhadap penurunan kadar kolesterol ketika diberi kapsul daun kelor. Peran dari senyawa bioaktif yaitu sitosterol pada daun kelor mampu meningkatkan fungsi usus dalam menyerap lemak sehingga kadar kolesterol dapat turun. Selain itu, kapsul daun kelor mengandung vitamin $A$, vitamin $C$, vitamin $B$, kalsium, kalium, besi dan protein dalam jumlah sangat tinggi yang mudah dicerna dan diasimilasi oleh tubuh manusia dan memiliki kandungan kalsium, protein serta kalium. ${ }^{29}$ Hal ini yang menunjukkan bahwa kapsul daun kelor lebih berpengaruh terhadap kolesterol disbandingkan teh hijau.

Hasil mengenai pengaruh teh hijau terhadap kadar koleseterol dalam darah masih kontroversial karena perbedaan dosis dan durasi dari penelitian-penelitian yang ada. Berdasarkan literature yang sudah di review, didapatkan perbedaan hasil jika dilihat berdasarkan pada dosis dan durasi pemberian teh hijau. Pada penelitian yang dilakukan oleh Samavat (2016) yang memberikan 4 GTE (satu kapsul mengandung 843 mg EGCG) setiap hari selama 12 bulan, dengan hasil adanya penurunan signifikan pada TC, LDL dan non-HDL. ${ }^{11}$ Sedangkan penelitian yang dilakukan oleh Huang (2018) yang memberikan satu kapsul $(856,8 \mathrm{mg}$ EGCG), tiga kali sehari, selama 6 minggu hanya menurunkan kadar LDL dan tidak ada perbedaan statistik terhadap kadar TC, TG dan HDL antara kelompok yang diberikan GTE dan placebo. ${ }^{12}$ Meskipun demikian, dari kedua penelitian ini menunjukkan bahwa pemberian dengan dosis lebih tinggi dan durasi yang lebih lama menunjukkan hasil yang lebih baik. Hal ini didukung oleh hasil penelitian yang dilakukan oleh Mawarti (2012) yang menunjukkan kadar TC menurun signifikan pada dosis $8 \mathrm{mg} / \mathrm{kgBB} 55 \%$ jika dibandingkan dengan kelompok yang diberikan dosis $1 \mathrm{mg} / \mathrm{kgBB}$ dan 2 $\mathrm{mg} / \mathrm{kgBB} .{ }^{14}$ Hal ini dikarenakan tinggi dosis dan lama pemberian merupakan 
salah satu faktor yang berpengaruh terhadap hasil penelitian ini, apabila dosis terlalu rendah dan waktu pemberian hanya singkat maka pengaruhnya juga tidak sebaik bila dibandingkan dengan kelompok yang diberikan dosis yang lebih tinggi dan dengan durasi yang lebih lama.

\section{SIMPULAN}

Antioksidan pada teh hijau dapat menurunkan kadar kolesterol dalam darah. Teh hijau merupakan bahan minuman yang sudah dikenal oleh masyarakat dan sangat mudah ditemukan serta harganya relatif murah. Pengetahuan tentang efek antioksidan teh hijau terhadap penurunan kadar kolesterol juga sangat bermanfaat karena dapat menjadi obat alternatif yang aman bagi kesehatan. Hal ini sangat baik diketahui karena hiperkolesterolemia masih menjadi masalah kesehatan yang banyak ditemukan di dunia. Perlu dikaji lebih dalam mengenai teh hijau terkait dengan pengaruhnya terhadap kadar kolesterol dalam darah.

\section{Konflik Kepentingan}

Penulis menyatakan tidak terdapat konflik kepentingan dalam studi ini.

\section{DAFTAR PUSTAKA}

1. Zahrawardani D, Herlambang KS, Anggraheny HD. Analisis Faktor Risiko Kejadian Penyakit Jantung Koroner di RSUP Dr Kariadi Semarang. J Kedokt Muhammadiyah. 2013;1(3):1-13.

2. World Health Organization. Raised Cholesterol. 2016. Available from: http://www.who.int/gho/ ncd/risk_factors/cholesterol_text/ en/. Accesed on: September $5^{\text {th }}$ 2020.

3. Riset Kesehatan Dasar. Laporan Nasional Riset Kesehatan Dasar 2018. 2018. Available from: http://www.yankes.kemkes.go.id/ assets/downloads/PMK No. 57 tahun 2013 tentang PTRM.pdf.
Accesed on: November $18^{\text {th }}$ 2020.

4. Oktora L, Kumala R, Staf S, Program P, Farmasi S, Pendahuluan UJ. Pemanfaatan Obat Tradisional Dengan Pertimbangan Manfaat Dan Keamanannya. Maj Ilmu Kefarmasian. 2006;III(1):1-7.

5. Zalmi H, Gemasih MIS, Rahmadani A. Jenis Jenis Obat-Obatan Dan Manfaatnya Bagi Mahkluk Hidup. INA-Rxiv; 2019. Available from: https://osf.io/ preprints/inarxiv/z7tf2. Accesed on: September $16^{\text {th }} 2020$.

6. Murase T, Nagasawa A, Suzuki J, Hase T, Tokimitsu I. Beneficial effects of tea catechins on diet-induced obesity: Stimulation of lipid catabolism in the liver. Int $\mathbf{J}$ Obes. 2002;26(11):1459-64.

7. Lelita D, Rohadi M, Putri A. Sifat Antioksidatif Ekstrak Teh (Camelia Sinesis) Jenis Teh Hijau, Teh Hitam, Teh Oolong dan Teh Putih dengan Pengeringan Beku (Freeze Drying). Jurnal TPHP Universitas Semarang 2013;4:15-30.

8. Roy H, Lundy S, Kalicki B. Green Tea: Metabolic Influences. Pennington Nutrition Series. 2007;(9):4.

9. Kao YH, Hiipakka RA, Liao S, Dulloo AG. Modulation of obesity by a green tea catechin [1] (multiple letters). Am J Clin Nutr. 2000;72 (5):1232-34.

10. Astari N. Pengaruh Pemberian Teh Hijau Terhadap Penurunan Kadar Kolesterol pada Lansia Awal (46-55) Tahun. Anal pendapatan dan tingkat Kesejaht rumah tangga petani. 2017;5:76-82.

11. Samavat H, Newman AR, Wang R, Yuan JM, Wu AH, Kurzer MS. Effects of green tea catechin extract on serum lipids in postmenopausal women: A randomized, placebo-controlled clinical trial1,2. Am J Clin Nutr. 2016;104(6):1671-82. 
12. Huang LH, Liu CY, Wang LY, Huang CJ, Hsu CH. Effects of green tea extract on overweight and obese women with high levels of low density-lipoproteincholesterol (LDL-C): A randomised, double-blind, and cross-over placebo-controlled clinical trial. BMC Complement Altern Med. 2018;18(1):1-11.

13. Sarel Z, Simanjuntak K. Pengaruh Pemberian Ekstrak Teh Hijau (Camellia sinensis L.) terhadap Penurunan Kadar Kolesterol Total Tikus Wistar (Rattus norvegicus) Diabetes Induksi Aloksan. J Sehat Mandiri. 2020;15(1):98-111.

14. Mawarti H. Penghambatan Peningkatan Kadar Kolesterol pada Diet Tinggi Lemak oleh Epigallocatechin Gallate (EGCG) Teh Hijau Klon Gmb4. Jurnal Unipdu 2012; 4.

15. Wu AH, Spicer D, Stanczyk FZ, Tseng CC, Yang CS, Pike MC. Effect of 2-month controlled green tea intervention on lipoprotein cholesterol, glucose, and hormone levels in healthy postmenopausal women. Cancer Prev Res 2012;5(3):393-402.

16. Suliburska J, Bogdanski P, Szulinska M, Stepien M, Pupek-Musialik D, Jablecka A. Effects of green tea supplementation on elements, total antioxidants, lipids, and glucose values in the serum of obese patients. Biol Trace Elem Res 2012;149(3):315-22.

17. Budi E, Emah M, Yunita S. Pemberian Teh Hijau Terhadap Kadar Kolesterol Total Mencit Jantan yang Diberi Diit Tinggi Lemak. J Keperawatan. 2015;1(1):18-24.

18. Chen IJ, Liu CY, Chiu JP, Hsu CH. Therapeutic effect of high-dose green tea extract on weight reduction: A randomized, double-blind, placebo-controlled clinical trial. Clin Nutr. 2016;35 (3):592-9.

19. Harahap, Apriana. Pengaruh Pemberian Seduhan Daun Teh Hijau Terhadap Kolesterol Total dan HDL pada Mencit (Mus Musculus) Diabetes Melitus Tipe 2. Universitas Sumatera Utara. 2016;31-5.

20. Erlyn P, Nyayu F, Salma K, Bella JS, Aprilia., Sartika S. Perbandingan Daun Teh Hijau dan Daun Pare Terhadap Penurunan Kolesterol. Syifa Med. 2020;11(1).65-70.

21. Maydawati V, Veri N. Potensi Teh Hijau dalam Menurunkan Kadar Kolesterol pada Akseptor Kontrasepsi Progestin Hiperkolesterolemia. J Healthc Technol Med. 2020;6(2):1031-6.

22. Astuti GD, Fitranti DY, Anjani GY, Afifah DN, Rustanti N. Pengaruh Pemberian Yoghurt dan Soyghurt Sinbiotik Kayu Manis (Cinnamomum Burmanii) terhadap Kadar Trigliserida dan Total Kolesterol pada Tikus PraSindrom Metabolik. Gizi Indonesia 2020;43(2):57-66.

23. Chen IJ, Liu CY, Chiu JP, Hsu CH. Therapeutic effect of high-dose green tea extract on weight reduction: A randomized, double-blind, placebo-controlled clinical trial. Clin Nutr. 2016;35(3):592-9.

24. Astari NMSN, Udaya M, Rahmawati IMH. Memberikan Informasi Kepada Petugas Kesehatan Mengenai Pemberian Teh Hijau Dapat Menurunkan Kadar Kolesterol Pada Lansia Awal . Jurnal Insan Cendekia. 2018;8(1):1-7.

25. Maydawati V, Veri N. Potensi Teh Hijau dalam Menurunkan Kadar Kolesterol pada Akseptor Kontrasepsi Progestin Hiperkolesterolemia. J Health Technol Med. 2020;6 (2):1031-6.

26. Carolyn A, Farishal A, Berawi K. Potensi Pemberian Isoflavon 
Kedelai Terhadap Kadar Kolesterol Total dan LDL pada Penderita Obesitas. Jurnal Kedokteran Universitas Lampung. 2019;9: 102-6.

27. Hassan S, Ejerish M, Herba U. Vitamin E Ameliorate the Lipids Problem Induces by Contraceptives. J Chem Inf Model. 2019;53(9):1689-99.

28. Hapsari YT, Kusumastuti AC. Pengaruh Vitamin C terhadap Kadar Low Density Lipoprotein
(LDL) Lanjut Usia setelah Pemberian Jus Lidah Buaya (Aloe barbadensis Miller). J Nutr Coll. 2014;3(4):770-6.

29. Anugerahwati, Indar Ra. Pengaruh Pemberian Kapsul Daun Kelor terhadap Penurunan Kadar Kolesterol pada Ibu Post Menopause Di Wilayah Kerja Puskesmas Tamamaung. Mitra Sehat 2018; VIII(November):38999. 